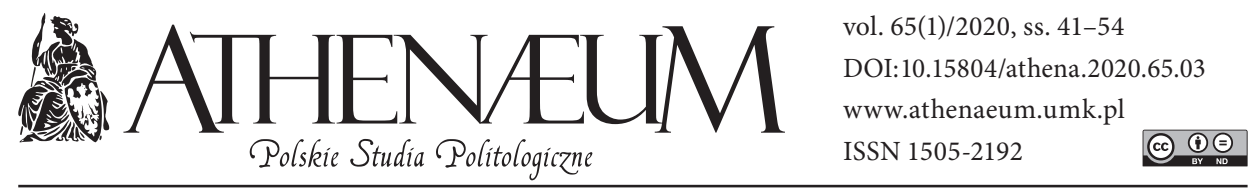

\title{
PARTIA POLITYCZNA W PORZACDKU PRAWNYM WIELKIEJ BRYTANII
}

\author{
POLITICAL PARTY IN THE UK STATUTE LAW
}

Dagmara Suberlak*

\begin{abstract}
ABSTRAKT
Artykuł dotyczy procesu tworzenia systemu partyjnego w Wielkiej Brytanii. Występowanie odmiennego funkcjonowania partii politycznej Wielkiej Brytanii ma związek z prawem stanowionym. Artykuł dotyczy: procesu instytucjonalizacji partii politycznych, funkcji partii politycznych w Wielkiej Brytanii na podstawie ustaw: ustawy o rejestracji partii politycznej 1998 (Registration of Political Parties Act 1998), ustawy o partiach politycznych, wyborach i referendach 2000 (Political Parties, Elections and Referedum Act 2000), ustawy o partiach politycznych i wyborach z 2009 (Political Parties and Elections Act 2009) i ustawy o systemie wyborczym w wyborach parlamentarnych oraz o okręgach wyborczych (Parliamentary Voting System and Constituencies Act 2011). Zwrócono uwagę na system normatywny instytucji rządu większościowego w koncepcji partii politycznych i reform konstytucyjnych rządu. Przedmiotem zainteresowania stał się system dwupartyjny Wielkiej Brytanii i rola organów państwowych. W artykule dostrzeżono różne prawne, jak i praktyczne skutki reform konstytucyjnych w systemie parlamentarno-gabinetowym.
\end{abstract}

Słowa kluczowe: system polityczny; brytyjski system partyjny; instytucjonalizacja partii politycznych
The article deals with the process of creating a party system in Great Britain. The existence of a different functioning of the UK political party is related to statute law. The article concerns the process of institutionalizing political parties, as well as the functions of political parties in Great Britain based on the following acts: Registration of Political Parties Act 1998, Act on Political Parties, Elections and Referendums 2000 (Political Parties, Elections and Referendum Act 2000), the Political Parties and Elections Act 2009, and the Act on the electoral system in parliamentary elections and on constituencies (Parliamentary Voting System and Constituencies Act 2011). Attention was paid to the normative system of majority government institutions in the concept of political parties and constitutional reforms of the government. The subject of interest became the two-party system of Great Britain and the role of state organs. The article notices various legal and practical effects of constitutional reforms in the parliamentary and cabinet system.

Keywords: political system; British party system; institutionalization of political parties

* Uniwersytet Kazimierza Wielkiego w Bydgoszczy, Wydział Nauk o Polityce i Administracji. 


\section{WSTĘP}

W opracowaniach opublikowanych dotychczas podejmowano różne aspekty funkcjonowania partii politycznych, struktury i dystrybucji władzy, organizacji wewnętrznej brytyjskiego parlamentu. Wskazać należy publikację autorstwa: A. Zięby, Parlament Wielkiej Brytanii, A. Antoszewskiego i R. Herbuta Demokracje Zachodnioeuropejskie. Analiza porównawcza, W. Sokoła M. Żmigrodzkiego, Współczesne partie i systemy partyjne. Zagadnienia teorii i praktyki politycznej oraz S. Bożyka Opozycja parlamentarna.

Jak dotąd nie ukazała się publikacja poświęcona problematyce prawnoustrojowej brytyjskich partii politycznych, a zwłaszcza kwestii takich, jak: status prawny, organizacja oraz funkcjonowanie partii politycznej. Zagadnienie to zasługuje na szczególną uwagę, ponieważ partia polityczna w systemie demokratycznym ma wpływ na proces rządzenia państwem, tworzenia rządu oraz działania opozycji w stosunku do władzy wykonawczej.

Problematyka partii politycznych w procesie instytucjonalizacji jest przedmiotem niniejszego opracowania. $\mathrm{W}$ wyniku prowadzonych badań zamierzam przedstawić drogę ustawodawstwa zwykłego w procesie instytucjonalizacji partii politycznych w Wielkiej Brytanii i udzielić odpowiedzi na postawiony problem badawczy: w jakim stopniu normy konstytucyjne i konwenanse konstytucyjne wpływają na system partii politycznych? Istotne jest udzielenie odpowiedzi na to pytanie badawcze. $\mathrm{W}$ niniejszej pracy celem podjętego zagadnienia była analiza jakościowa ustaw parlamentarnych dotyczących funkcjonowania partii politycznych w Wielkiej Brytanii oraz analiza porównawcza systemu organów państwa oraz wymiaru funkcji partii politycznych.

Praca podzielona jest na cztery rozdziały. Rozpoczyna ją rozdział o charakterze ogólnym, w którym opisuję cechy oraz istotę procesu instytucjonalizacji, a także rozróżnienie w systemie ustrojowym Wielkiej Brytanii. W rozdziale drugim znalazła się analiza jakościowa ustaw parlamentarnych w oparciu o zasady demokratycznego państwa prawa. W trzeciej części omawiam problematykę roli partii politycznych w tworzeniu gabinetu jednopartyjnego i rządu większościowego. Konieczne było uznanie zasad prawnoustrojowych systemu parlamentarno-gabinetowego. Niniejsza praca poświęcona jest funkcjonowaniu partii politycznych w oparciu o regulacje ustawowe, konwenanse konstytucyjne oraz zwyczaje konstytucyjne. 


\section{ISTOTA I POJĘCIE INSTYTUCJONALIZACJI}

Powstanie partii politycznych ma związek z systemem partyjnym. Przede wszystkim partie polityczne stanowią formalne ugrupowania polityczne o charakterze celowych zrzeszeń, mające możliwość egzekwowania politycznej odpowiedzialności organów państwa, stanowiące niezbędny element systemu demokratycznego.

To właśnie S. Bożyk (2005) zauważa, że: „w niektórych systemach rządów (Wielka Brytania, Australia, Kanada) działalność frakcji parlamentarnych opiera się z kolei przede wszystkim na niepisanych i utrwalonych w praktyce ustrojowej niepisanych zwyczajach oraz konwenansach konstytucyjnych". Tak więc w system politycznym Wielkiej Brytanii istotne znaczenie ma działanie organów władzy w oparciu o normy konstytucyjne i konwenansowe oraz niepisane zwyczaje.

Zanim przejdziemy do dalszych rozważań, należy wyjaśnić jeszcze inną kwestię. Jak wygląda polityczna instytucjonalizacja partii politycznych? Czy odnosi się ona do funkcji legislatywy, gdzie wybiera się deputowanych, czy też do egzekutywy, gdzie tworzy się gabinety koalicyjne?

Instytucjonalizacja partii politycznych ma zróżnicowany charakter. Jeśli podstawowe znaczenie ma wymiar funkcji partii politycznych jako elementu systemu politycznego, o tyle określenie go w sposób mniej konkretny może wzbudzać wątpliwości. Należy podkreślić, że znaczenie partii politycznych będzie zależne od ustroju politycznego, co może powodować trudności w interpretacji regulacji ich statusu. Partie polityczne są częścią systemu politycznego, ale w odniesieniu do systemu partyjnego relacje między nimi mogą je destabilizować (Sokół, Żmigrodzki, 2003).

Ujęcie funkcjonalne nie jest jedynym kryterium zróżnicowania partii politycznych. S. Bożyk, opierając się na działaniu partii politycznych w ramach danego państwa, wyróżnił model funkcjonowania opozycji jako ogniwa łączącego rządową większość i partie opozycyjne: model opozycji konfrontacyjnej, nazywanej modelem konkurencyjnym, i model koncyliacyjny, inaczej kompromisowy. W Wielkiej Brytanii mamy przykład modelu konfrontacyjnego, w którym funkcje premiera obejmuje lider zwycięskiej partii politycznej, a opozycja nie ma prawa w sprawowaniu rządów (Bożyk, 2005).

Zupełnie odmienną klasyfikację przeprowadzili badacz A. Zięba; z jego punktu widzenia brytyjski system polityczny stanowi rezultat rywalizacji między partiami politycznymi. Badacze, m.in. A. Zięba, zdefiniowali dwupartyjny system polityczny w stosunku do kierowniczej roli polityki partii rządzącej: 
„Rozstrzygnięcia normujące różne aspekty działalności partii tworzą strukturę dalece niejednorodną pod względem formalnym... czyni tym samym partię podmiotem jednego z aktów ustrojowych państwa" (Grzybowski i in., 1996).

Zdaniem A. Zięby ta właściwość wskazuje na swoistość brytyjskiego podejścia do instytucjonalizacji partii, stąd brytyjska doktryna prawa konstytucyjnego podnosi „wspólnotę idei dotyczących struktury organizacyjnej partii i ustroju państwa", regulowanych normami prawa konstytucyjnego i normami zwyczajów konstytucyjnych oraz uznaje za pełnoprawny składnik konstytucji „zasady określające wewnętrzny porządek partii politycznych" (Grzybowski, in., 1994).

Ostatnia $\mathrm{z}$ wymienionych koncepcji procesu instytucjonalizacji różni się od wcześniejszych zaprezentowanych charakterem powiązań partii politycznej z otoczeniem. Zgodnie z zaprezentowaną przez A. Panebianco koncepcją organizacyjną partii politycznych system norm i reguł sprzyja instytucjonalizacji. Zdaniem A. Panebianco w wymiarze autonomizacji partia może przetrwać mimo nieprzychylnego otoczenia politycznego. Po drugie stopień organizacyjności partii politycznej może oddziaływać na frakcje wewnątrz partii. Dlatego też otoczenie partii politycznych, jak i jej wymiar strukturalny, wpływa na ich instytucjonalizację ( Antoszewski, Herbut, 2003).

Od procesu instytucjonalizacji w sensie prawnym odróżnia ją istnienie reguł i norm, które jest uzasadnione autonomią decyzyjną danej frakcji parlamentarnej. Dotyczą one kwestii strukturalnych czy politycznych. W przypadku koncepcji A. Panebianco znaczny poziom instytucjonalizacji dotyczy struktury organizacyjnej partii politycznych i ich parlamentarnej aktywności. Jest to odmienne podejście związane z procesem instytucjonalizacji, niemające charakteru normatywnego, a przez to niepodlegające konwenansowym normom konstytucyjnym.

Polityczna forma instytucjonalizacji zależy od przyjętych w danym państwie zasad ustroju politycznego. Jak zauważa R. Hebut (2002): „partia polityczna”, „instytucja polityczna” w literaturze oraz języku potocznym są używane zamiennie. Biorąc pod uwagę strukturę partii politycznej, podlega określonym stosunkom politycznym i pełni odmienne funkcje wyborcze.

Instytucję zdefiniować można jako wyodrębniony zespół osób dysponujących określonymi zasobami organizacyjnymi oraz materialnymi, które pozwalają mu na udział w życiu politycznym (Herbut, 2002).

W definicji można wskazać, że instytucja jest podmiotem: ludzkich działań i zachowań podlegającym zmianom. Uwzględnienie pierwszego elementu pozwala odróżnić instytucję polityczną od organizacji o charakterze politycznym, jak i od jej składników funkcjonujących w życiu politycznym. Drugi wskazany 
element definicji - podlega zmianom w kontekście partii politycznych i ich funkcji wyborczych. Jego znaczenie może być kwestionowane w odniesieniu do wielkich grup społecznych, w których liderzy próbują przejąć władzę. Nawet jednak w nich podmioty używają interesu do osiągania korzyści jako maksymalizacji potrzeb. Wykorzystanie interesu instytucji politycznej i podkreślanie występowania wyłącznie we własnym interesie osłabiłby legitymację koncepcji wspólnoty celów.

Z przytoczonej definicji wynikają funkcje partii politycznych, a podstawową jest rządzenie państwem. Istotną rolę odgrywa przywódca, który w stosunku do pozostałych członków będzie pełnił rolę kierowniczą. W sytuacji wyborów parlamentarnych liderzy partii tworzą program wyborczy, służący mobilizacji elektoratu i decydujący o jego akceptacji przez wyborców.

Patrząc przez pryzmat praktyki ustrojowej Wielkiej Brytanii, należy stwierdzić, że to monarcha w „normalnych” warunkach mianuje premiera, kiedy partia uzyskuje większość w parlamencie. Zawieszenie prac parlamentu (hung parliament) następuje w wyniku nieuzyskania bezwzględnej większości w izbach.

Wydaje się, że w warunkach państwa demokratycznego wybór lidera partii może wpływać na system partyjny. W latach 1996-2010, używając systemu „One Member One Vote”, liderzy partii politycznych Partii Konserwatywnej (Conservative Party) i Partii Pracy (Labour Party) byli wybierani przez członków partii, a nie elity partyjne czy parlamentarzystów (Denham, 2012). Wybór przewodniczącego nie jest regulowany przez normy konwenansowe, ale dla zapewnienia prawidłowego funkcjonowania brytyjskiego parlamentu premier musi być członkiem Izby Gmin.

Istotną rolę w procesie rządzenia odgrywa uzyskanie legitymizacji przez wyborców. Uzyskanie większości parlamentarnej powodowało, że partie zwycięskie mogły kształtować rząd i wpływać na proces rządzenia. Podobne rozwiązania znaleźć można w parlamencie Szkocji, gdzie od 1999 r. trzy razy z rzędu utworzono rząd większościowy, a w 2007 r. największa partia polityczna, czyli Szkocka Partia Narodowa (Scotish National Party), utworzyła rząd mniejszościowy (Paun i Hazell, 2010).

Utworzenie koalicji Partii Pracy (Labour Party), Liberalnych Demokratów (Liberal Democrats) oraz Szkockiej Partii Narodowej (Scotish National Party) gwarantowało stabilizację rządów partii. Partie te, biorąc udział w przetargach koalicyjnych, utworzyły wspólny program rządowy. Powołanie premiera stało się efektem negocjacji, a w państwie demokratycznym stabilizacji systemu parlamentarno-gabinetowego (Seyd, 2004); The Scotish Parliament, 1999). 
Jak zauważa R. Herbut, w ujęciu historycznym lub socjologicznym, partia polityczna w kontekście zmiany politycznej ma do wypełnienia pewne zadania w następstwie pojawienia się pewnego rodzaju wyzwań i wymagań (Herbut, 2002).

Z punktu widzenia zmieniającego się otoczenia politycznego instytucja w kontekście ujawnienia się określonego łańcucha zdarzeń oraz przyjęcia nowych norm instytucjonalnych - oznacza znalezienie rozwiązań w kontekście kolektywnego działania w sferze społecznej. Rozwiązania instytucjonalne, wykorzystywane instrumenty i procedury $\mathrm{w}$ formach organizacyjnego rozwoju pozwalają stwierdzić, że instytucjonalizacja partii politycznych wywiera wpływ na jej istnienie. To ten system wartości będzie pełnił funkcję nadrzędną w stosunku do organizacji wewnętrznej tej organizacji do określenia programu na potrzeby społeczeństwa. Nie byłoby to możliwe bez uprzedniej strategii politycznej i jej funkcjonowania w organach partii politycznych.

W procesie kreowania określonego typu instytucji co do dalszego jej rozwoju oraz spojrzenia na zjawisko instytucjonalizacji partii politycznych przekłada się na wiele różnorodnych elementów. Znalazły się wśród nich: pojawienie się formalnych reguł gry w wyniku procesu demokratyzacji partii politycznych; występowanie określonych idei, przekonań, uprzedzeń w aspekcie szeroko rozumianej kultury; występowanie wewnętrznego mechanizmu organizacyjnego partii politycznych (Herbut, 2002).

Powyższe zestawienie elementów procesu instytucjonalizacji partii politycznych wydawało się za ogólne - zestawienie formalnych reguł gry z tak szczegółowym ustawodawstwem danego państwa utrudniało określenie koncepcji instytucjonalizacji partii politycznych. Dodatkowo wątpliwości może budzić zestawienie aż trzech elementów w odniesieniu do partii politycznych państwa niebędącego systemem rządów demokratycznych.

Warto zauważyć, że instytucjonalizacja partii politycznych w wyniku „rutynizacji zachowań i stabilności”, dotyczących norm i procedur zakresu instytucjonalizacji, mimo wyposażenia partii politycznej w niezbędne dla niej zdolności adaptacyjne, w warunkach nowego otoczenia, tę partię zmienia (Herbut, 2002). Jednak gwarancja ciągłości organizacyjnych staje się „formą hierarchicznej stabilności” partii politycznej. W gruncie rzeczy zadanie to było kontynuacją adaptacji partii politycznej do otoczenia w latach wcześniejszych. Funkcja ta $\mathrm{w}$ dotychczasowej formule straciła rację bytu w wyniku organizacyjnych przekształceń systemu politycznego.

Z drugiej jednak strony instytucjonalizacja partii politycznych oznacza stopniowy wzrost znaczenia jej zdolności funkcji adaptacyjnych kosztem funk- 
cji zapewnienia jej stabilności wewnętrznej, z partii politycznej o charakterze wspólnoty interesów w kierunku ,scentralizowanej i zhierarchizowanej struktury terytorialnej opartej na rozbudowanym układzie powiązań terytorialnych" (Herbut 2002).

\section{USTAWY O PARTIACH POLITYCZNYCH}

System partyjny związany jest z ewolucją sprawowania władzy politycznej. Jak zauważa A. Zięba: „inaczej niż w Wielkiej Brytanii, gdzie wykształcone przez praktykę zasady regulujące działalność partii politycznej wzrastały w konstytucję brytyjską na tych samych prawach co rozstrzygnięcia dotyczące np. parlamentu czy gabinetu". W rezultacie do pierwszej instytucjonalizacji partii politycznej doszło w 1765 r., przy czym było to wynikiem nie tylko działalności partii politycznych, ale regulaminów (Zięba, 1995).

Trzeba jednak zauważyć, że zwyczaje konstytucyjne miały charakter uzupełniający. $Z$ formalnego punktu widzenia status partii politycznych nie był skutkiem ustaw wydawanych przez parlament.

Zwyczaj konstytucyjny „lojalności posła” zwracał uwagę na rodzaj organizacyjnej działalności partii na terenie parlamentu. Wychodząc od analizy doktryny prawa konstytucyjnego, dwoisty charakter instytucjonalizacji partii politycznej był wynikiem funkcji rządzenia. Na tej podstawie kompetencji władzy ustawodawczej wyznaczane były szczegółowe funkcje partii w parlamencie. Względem czego działanie partii na terenie parlamentu określały funkcje pełnione przez te partie, czyli tzw. zadania będące realizacją różnych funkcji partii politycznych.

Do instytucjonalizacji prawnej partii politycznej w Zjednoczonym Królestwie doszło w latach 90. XX w. Ogłoszona w 1998 r. przez parlament brytyjski ustawa o rejestracji partii 1998 (Registration of Political Parties Act 1998) politycznej kładła nacisk na system rejestracji partii politycznych w następstwie trybu zmiany konstytucji Zjednoczonego Królestwa oraz systemu parlamentarno-gabinetowego (Parliament of the United Kingdom). Na podstawie ustawy o rejestracji partii politycznych z $1998 \mathrm{r}$. tworzenie partii politycznych następowało na poziomie organizacji politycznej. Wychodząc od działalności partii politycznych, organizacja polityczna definiowała konkretne cele na rzecz polityki państwa. $\mathrm{Na}$ podstawie programów politycznych wyznaczane były szczegółowe zadania na rzecz państwa. Wobec nich organizacje polityczne określały konkretne cele, tzw. statuty, czyli artykulacje potrzeb służących osiąganiu celów. 
Na podstawie art. 2 system rejestracyjny wprowadził konieczność rejestracji partii politycznych. Kryterium dotyczyło: 1) wyborów powszechnych; 2) wyborów do Parlamentu Europejskiego; 3) wyborów do Parlamentu Szkocji; 4) wyborów do Zgromadzenia Narodowego Walii; 5) wyborów do „Nowego Zgromadzenia” Irlandii Północnej; 6) wyborów samorządowych; 7) wyborów samorządowych w Irlandii Północnej. Wskazane rejestry partii politycznych stanowiły zestawienie głosowań do wyborów powszechnych, które były daleko idącą modyfikacją systemu wyborczego.

W rezultacie system instytucjonalizacji prawnej dotyczył ogólnej rejestracji partii politycznej, której przedmiotem było zgłoszenie nazwy, siedziby i znaków specjalnych (maksymalnie 3 godła, artykuł 5). Jasno został również określony skład osób rejestrujących partię. Stanowił go: 1) oficer nominujący;2) lider partii (artykuł 9) (Parliament of the United Kingdom). Należy zauważyć, że system wyborczy Wielkiej Brytanii wprowadził ogólne zasady dotyczące rejestracji partii politycznych. Artykuł 21 tego aktu przewiduje, że funkcja ewidencji dotyczyła prowadzenia działalności prawnej i uzyskania posiadania majątku przez partię polityczną.

Odnośnie do tej ustawy dalsze regulacje zawarto w ustawie o partiach politycznych, wyborach i referendach 2000 (Political Parties, Elections and Referendums Act 2000) z 2000 roku (Parliament of the United Kingdom). Zgodnie $\mathrm{z}$ tą ustawą unormowania uzupełniały rejestrację partii politycznych na terenie Wielkiej Brytanii i Irlandii Północnej. Artykuły 22 - 40, rozdz. II, wymieniały „nowe rejestry” partii politycznych, które dotyczyły państw federalnych.

Zgodnie artykułami 41-49, rozdz. III, działalność partii politycznych podlega finansowaniu ze źródeł, z których partie mogą czerpać środki na prowadzenie działalności. Artykuł 50, rozdz. IV, wymienia: 1) prezenty w sensie pieniędzy lub nieruchomości; 2) wszelką działalność sponsorowaną; 3) składki członkowskie 4) „wydane pieniądze”, 5) wszelkie pieniądze pożyczone inaczej niż na warunkach handlowych; 6) zapewnione nieruchomości, usługi. Zgodnie z rozdz. I i II cz. IV finansowanie partii politycznych było dozwolone w przypadku poinformowania o kwocie darowizny pieniężnej przez odpowiednie organy partii politycznych państw federalnych. Wskutek tego ustawa wprowadziła obowiązek informowania o rejestracji darowizny, dokonując tym samym ugruntowania prawnego partii politycznych (Electoral Commision).

Do rozwoju instytucjonalizacji partii politycznych Wielkiej Brytanii przyczyniło się uchwalenie ustawy o partiach politycznych i wyborach 2009 (Political Parties and Election Act 2009) z 2009 r. (Parliament of the United Kingdom). 
Ustawa dotyczyła: wspierania działalności organów administracji państwowej (artykuły 1-8, rozdz. I i artykuły 23-27, rozdz. III); uregulowanie systemu kontroli partii politycznych (artykuły art. 9-22, rozdz. II) oraz wspierania systemu rejestracji (artykuły 28-37, rozdz. IV). Zgodnie z art. 4 i 6 rozdz. I w przypadku głosowania zmieniono liczbę Komisji Wyborczych, stanowiąc, że liczba komisarzy wyborczych będzie wynosiła od 9 do 10 (Electoral Commission). Komisja Wyborcza miała zostać powoływana przez partie polityczne, a jej członkowie nie mogli być zaangażowani politycznie przez okres 5 lat. W wyniku przyjętej ustawy zwiększono kwoty darowizny i kredytów z 200 funtów brytyjskich do 500, pożyczki z 5000 do 75000 funtów brytyjskich dla sztabów oraz od 1000 do 1500 za jednostki księgowe na rzecz partii politycznych (Electoral Commision). Wprowadzenie tych zapisów doprowadziło do zwiększenia uprawnień administracji państwowej, która wcześniej nie posiadała kompetencji kształtujących system partyjny. Po ich reformie organy państwa uzyskały możliwość zdobycia większej niż dotychczas liczby urzędów, co pozostawało w asymetrii do obowiązującego systemu rejestracyjnego partii politycznych.

W odniesieniu do głosowania z $2011 \mathrm{r}$. dalsze regulacje zawarto w ustawie o systemie wyborczym w wyborach parlamentarnych oraz o okręgach wyborczych (Parliamentary Voting System and Constituencies Act 2011) (Parliament of the United Kingdom). W zakresie przedmiotowym tryb wyboru organów przedstawicielskich w Zjednoczonym Królestwie nie budził większych wątpliwości, gdyż wiązał się z funkcją wyrażenia woli wyborcy, tzn. przeprowadzenia referendum w sprawie alternatywnego sposobu głosowania.

Zgodnie $\mathrm{z}$ artykułem 11 ustawy unormowania dotyczyły zakresu terytorialnego. Były nimi okręgi wyborcze w liczbie 600 (Parliamentary Voting System and Constituencies Act 2011). Takie ujęcie wspólnych okręgów wyborczych dla Szkocji, Anglii, Walii, Irlandii Północnej w wyborach samorządowych, lokalnych czy Parlamentu Europejskiego było jednak związane z wyznaczeniem granic niemogących wchodzić w skład hrabstw i ich okręgów wyborczych. Co do zasady jednak, wybory w okręgach wyborczych służyły równości wyborców w liczbie członków organu przedstawicielskiego.

Jak już wspomnieliśmy, w sensie przedmiotowym w trybie wyboru organów przedstawicielskich w Wielkiej Brytanii do 2000 r. funkcjonowały aż 4 systemy wyborcze. Zgodnie z referendum, które odbyło się w 2011 r., piąty system wyborczy „alternatywny sposób głosowania” miał być wprowadzony po zatwierdzeniu w referendum. $Z$ powodu odrzucenia przez wyborców rozwiązanie wycofano (Bogdanor, 2011).Z punktu widzenia instytucji referendum jego wprowadzenie 
należy uznać za kluczową zmianę, która zwiększyła udział elektoratu w procesie wyborczym.

Zgodnie z regulacją ustawową - ustawą o systemie wyborczym w wyborach parlamentarnych oraz o okręgach wyborczych (Parliamentary Voting System and Constituencies Act 2011) - zakres okręgów wyborczych obejmował obszary terytorialne niebędące terytorium Zjednoczonego Królestwa. Jego obszar administracyjny związany z realizacją wyborów parlamentarnych i referendum uległ zmniejszeniu. W praktyce liczba okręgów wyborczych zależała od decyzji Komisji Wyborczej powołanej do życia ustawą o partiach politycznych, wyborach i referendach (Political Parties, Elections and Referendums Act 2000) z 2000 r. $\mathrm{Z}$ tego punktu widzenia okręgi wyborcze należało traktować jako wskaźnik podziału państwa powołany przez Komisje Graniczne.

Od 2005 r. liczba przedstawicieli w szkockim parlamencie uległa zwiększeniu na podstawie ustawy o parlamencie Szkocji (Scotland Act 1998), co oznaczało stopniową likwidację okręgów wyborczych (Parliament of the United Kingdom). Chociaż w praktyce liczba okręgów mieściła od 60000 do 80000 wyborców, to jednak między okręgami istniały bardzo duże różnice. Generalnie średnia wielkość elektoratu dla całego okręgu Anglii była mniejsza niż dla pozostałych okręgów Szkocji, Walii i Irlandii Północnej (Grabowski, in., 2006).

W zakresie przedmiotowym jednomandatowe okręgi wyborcze były wynikiem funkcjonowania systemu dwupartyjnego. Jego cechą jest sprzęgnięcie zasady większości względnej w prawie wyborczym (Grzybowski, in., 1996).

Okręgi wyborcze w Wielkiej Brytanii minimalizowały praktyczną rolę tzw. partii trzecich na skutek dominacji dwóch wielkich partii utrzymujących się w układzie od roku 1922. Sprawowanie rządów w przypadku systemu dwupartyjnego było znacznie stabilniejsze niż w przypadku systemu większościowego. Warto zauważyć, że ordynacja wyborcza do obu izb sprzyjała funkcjonowaniu układu dwupartyjnego, w którym zwycięstwo wyborcze największej partii było wynikiem praktyki konstytucyjnej. W odniesieniu jednak do tradycji ustrojowej funkcjonowanie największej partii było związane z organami państwowymi. Konsolidacja systemu politycznego, która nastąpiła w wyniku nowelizacji ustaw parlamentarnych, prowadzi do wniosku, że każda partia w ramach systemu miała równe szanse na prowadzenie działalności. 


\section{ZASADY TWORZENIA RZĄDOWYCH KOALICJI W USTROJU WIELKIEJ BRYTANII}

Dwuizbowy parlament Wielkiej Brytanii jest wyłaniany na podstawie większościowej formuły wyborczej. W Wielkiej Brytanii dominującą izbą Parlamentu jest Izba Gmin, w której rządowe kierownictwo jest utrzymywane przez większość parlamentarną. Począwszy od lat 50. XX w., proces instytucjonalizacji partii politycznych zaczął się rozwijać dwuskładnikowo. Do jednego z tych czynników zaliczyć można upowszechnienie się zasad systemu rządów demokratycznych, a do drugiego wzrastające znaczenie roli przywódcy partyjnego (Silk, 1994).

Wydaje się więc, że w każdym przypadku wynik wyborów pozwalał utworzyć rządową większość i opozycję parlamentarną. Partia zwycięska decyduje o składzie rządu i parlamentu. W wyniku głosowania przed rokiem 1945 w systemie większości względnej utworzono 6 rządów mniejszościowych w ciągu 4 kadencji parlamentu. W 1974 r. powrócił rząd mniejszościowy, który nie uzyskał poparcia społecznego. Rządy Jamesa Callaghana i Johna Majora zostały w następnych latach zdymisjonowane z powodu nieuzyskania większości w Izbie Gmin (Paun, Hazell, 2010). Po raz drugi głosowanie w 2010 r. przyczyniło się do utworzenia rządu większościowego (Evans, 2012).

Jak zauważa R. Herbut, idąc za Giovannim Sartorim, znaczenie ugrupowań w kontekście określenia potencjału koalicyjnego i uznania tych partii za relewantne wpływa na kształt pewnych koalicji (Antoszewski, 2008).

Niewątpliwie prawdziwe jest stwierdzenie, że liczba uzyskanych mandatów jest efektem rywalizacji politycznej. Badacz A. Antoszewski (2004) wspomniał za koncepcją R. Dahrendorfa, że ów mechanizm przybiera postać gry politycznej, jej uczestnicy podporządkowują się istnieniu reguł, a osiągnięcie miejsc w rządzie jest narzędziem odpowiedzialności politycznej. Są to wybory rywalizacyjne, które odpowiadają założeniom systemu politycznego. Tak więc proces ten jest zależny od woli wyborców, wyłaniając się na tle legitymizacji.

Podkreślenia wymaga, że utworzenie rządu większościowego Partii Konserwatywnej i Partii Liberalnych Demokratów (Liberal Democrats) przyjęto z uwagi na chęć kontrolowania obu izb parlamentu i gabinetu. Formowanie się tego typu współpracy zapewniało stabilność władzy wykonawczej. Jednak większość członków Partii Konserwatywnej sprzeciwiała się powstaniu tego rządu (Evans, 2012). Poddawano pod wątpliwość, że taka formuła współpracy będzie wynikiem porozumienia z uwagi na kontrolowanie ministerstw przez większość Demokratów. Wprowadzenie rządu większościowego w 2010 r. było od roku 1997 
pierwszą wygraną Partii Konserwatywnej. Wśród przyczyn upadku tej współpracy poddawano osłabienie pozycji parlamentu oraz delegitymizowanie polityki rządu.

$\mathrm{Z}$ tego punktu widzenia utworzenie koalicyjnego rządu większościowego doprowadziło do zmian w strukturze parlamentu, w którym dominowały dwa największe ugrupowania: Partii Pracy i Partii Konserwatywnej. W wyniku wyborów powszechnych w roku 1974 i 2010 partie trzecie uzyskały możliwość zdobycia władzy, co oznaczało wybór premiera przez większość rządzącą.

Jak zauważa V. Bogdanor (2011), motywem przewodnim różnych reform konstytucyjnych było położenie nacisku na zmianę systemu politycznego. Istotą tego procesu była zasada suwerenności parlamentu, która stanowiła nieprzerwanie fundament brytyjskiego systemu politycznego.

Należy zauważyć, że parlamentarna forma rządów daje możliwość rozwiązania parlamentu premierowi. Jak zauważa R. Herbut, „w sytuacji pata parlamentarnego (partia) liderzy może stworzyć w ten sposób większość opartą na odnowionej legitymacji wyborczej" (Antoszewski, 2008).

W 2010 r. rząd premiera Davida Camerona zmienił ustawodawstwo w celu zablokowania możliwości rozwiązania parlamentu przez urzędujący rząd. Odbudowanie pozycji parlamentu stało się celem programu Partii Konserwatywnej w latach 2001 i 2005 (Flinders, 2009). W programach partii akcentowano potrzebę odbudowania zasady suwerenności parlamentu, wzmocnienia Izby Gmin, zmiany liczby ustaw rządowych, zmniejszenia liczby ministerstw, zachowania systemu większościowego oraz przyjęcia ustawy o kadencji parlamentu. W rezultacie partia sprzeciwiała się reformie westminsterskiego systemu rządów, federalizmowi i nadaniu kompetencji Izbie Lordów.

Co istotniejsze, przyjęcie programu Partii Konserwatywnej stało się propozycją do wprowadzenia reform niebędących programem rządu Blaira. „Westminsterski system rządów” miał obowiązywać po wprowadzeniu ustaw, które dawały władzę partii rządzącej.

Jak już wspomniano, motywem przewodnim reform konstytucyjnych była nowelizacja ustroju. Badacz T. Wieciech uważa, że uchwalenie ustawy o zakończeniu prac parlamentu (Fixed-term Parliaments Act), wyznaczającej po raz pierwszy w 800-letniej historii parlamentaryzmu na wyspach brytyjskich kadencyjność Izby Gmin, była właściwym dążeniem do powściągnięcia władzy szefa rządu (Zięba, 2011). Do tego rodzaju debaty odwołał się wicepremier Nick Cleg w rządzie premiera Davida Camerona, uzasadniając na forum Izby Gmin projekt ustawy wyznaczającej kadencję parlamentu (Zięba, 2011). Wspomniana ustawa parlamentu przyznała prawo do rozwiązania parlamentu partii rządzącej. 
Podkreślenia wymaga, że system reform, począwszy od lat 90., był pierwszą od przeszło pół wieku próbą reformy konstytucji Wielkiej Brytanii. Pierwsze reformy konstytucyjne przeprowadził w 1998 r. rząd premiera Tony’ego Blaira, natomiast kolejne wprowadził rząd premiera Davida Camerona w 2010 r. Zastosowanie reform miało jednak różne konsekwencje. Rząd Blaira wprowadził system mieszany w państwach federacji (Flinders, 2011).

Jak już wspomniano, na początku proces formowania się rządu w jednoizbowym parlamencie przybiera postać pośredniej formy udziału wyborców, którzy decydują o składzie i jego liderze. Z kolei wyborcy bezpośrednio decydują o jego składzie. Koalicje, które powstają, są wynikiem negocjacji międzypartyjnych. Określenie potencjału dwóch największych partii politycznych staje się kryterium, jakie stosują w przetargach koalicyjnych. Pojawienie się formalnych reguł gry, takich jak ustawa parlamentu o kadencyjności Izby Gmin (Fixed term Parliament Acts), pozwoliła na dekompozycję dotychczasowego układu sił oraz zachowań wyborczych. Podstawowy model, jakim jest brytyjski model dwupartyjny, opiera się konwenansach konstytucyjnych i zwyczajach w systemie prawnoustrojowym, a prawna instytucjonalizacja wynika wprost z konkretnych regulacji ustawowych.

\section{BibLIOGRAFIA:}

Antoszewski, A. (2004). Wzorce rywalizacji politycznej we współczesnych demokracjach europejskich. Wrocław: Wydawnictwo Uniwersytetu Wrocławskiego.

Bogdanor, V. (2011). An era of constitutional reform. The Political Quarterly, 81(1), 53-63. DOI: https://doi.org/10.1111/j.1467-923X.2010.02221.x.

Bożyk, S. (2005). Opozycja parlamentarna w Sejmie RP. Warszawa: Wydawnictwo Sejmowe.

Denham, A. (2012). From Ted to Ed: Electing British Party Leaders. The Political Quarterly, 83(3), 576-586. DOI: https://doi.org/10.1111/j.1467-923X.2012.02340.x.

Antoszewski, A., Herbut, R. (red.). (2008). Demokracje Zachodnioeuropejskie. Analiza porównawcza. Wrocław: Wydawnictwo Uniwersytetu Wrocławskiego.

Electoral Commission. (2000). Pobrane z: Overview of donation to political parties, http://www.electoralcommission.org.uk/_data/assets/pdf_file/0014/102263/to-donations-rp.pdf.

Evans, S. (2012). Reluctant Coalitionists: The Conservative Party and the Establishment of the Coalition Government in May 2010. The Political Quarterly, 83(3), 478-486. DOI: https://doi.org/10.1111/j.1467-923X.2012.02342.x.

Electoral Commission. (2010). The Political Parties and Elections Act in action. Pobrane z: http://www.electoralcommission.org.uk/_data/assets/pdf_file/0007/78919/PPE-Act---A-summary-guide-to-what-is-changing.update.26.01.10.pdf. 
Flinders, M. (2009). Conserving the Constitution? The Conservative Party and Democratic reneval. The Political Quarterly, 80(2), 248-258. DOI: https://doi. org/10.1111/j.1467-923X.2009.01983.x.

Grzybowski, M., Zięba, A. (red.). (1996). Współczesne systemy partyjne wybranych państw europejskich. Kraków: Wydawnictwo Uniwersytetu Jagiellońskiego.

Herbut, H. (2002). Teoria i praktyka funkcjonowania partii politycznych. Wrocław: Wydawnictwo Uniwersytetu Wrocławskiego.

Parliament of the United Kingdom. (1998). Scotland Act 1998. Pobrane z: http://www. legislation.gov.uk/.

Grabowska, S., Składowski, K. (red.). (2006). Prawo wyborcze do Parlamentu w wybranych państwach europejskich. Kraków: Wydawnictwo Zakamczycze.

Paun, A., Hazell, R. (2010). Hung Parliaments and the Challenges for Westminster and Whitehall: How to Make Minority and Multiparty Governance Work. The Political Quarterly, 81(2), 213-227.DOI: https://doi.org/10.1111/j.1467-923X.2010.02082.x. Parliament of the United Kingdom. (2011). Parliamentary Voting System and Constituencies Act 2011. Pobrane z: http://www.legislation.gov.uk/.

Parliament of the United Kingdom. (2000). Political Parties, Elections and Referendums Act 2000. Pobrane z: http://www.legislation.gov.uk/.

Parliament of the United Kingdom. (2009). Political Parties and Elections Act 2009. Pobrane z: http://www.legislation.gov.uk/.

Parliament of the United Kingdom. (1998). Registration of Political Parties Act 1998, Pobrane z: http://www.legislation.gov.uk/.

Silk, S. (1994). Jak działa parlament brytyjski? Warszawa: Wydawnictwo Sejmowe.

Seyd, B. (2004). Coalition Governance in Scotland and Wales. Pobrane z: https://core. ac.uk/download/pdf/16268585.pdf.

The Scotish Parliament. (1999). 1999 elections. Pobrane z: http://www.parliament.scot/ visitandlearn/Education/16286.aspx.

Wieciech, T. (2012). Wpływ ustawy o kadencyjności parlamentu (Fixed-term Parliaments Act, 2011) na brytyjski system rządów. W: Zięba, A. (red.). Konstytucjonalizm w państwach anglosaskich, (s. 245-272). Kraków: Uniwersytetu Jagiellońskiego.

Zięba, A. (1995). Z zagadnień instytucjonalizacji partii w brytyjskim porządku konstytucyjnym, Państwo i Prawo, 9 (595), 69-79.

Żmigrodzki, M., Sokół, M. (red.). (2003). Współczesne partie i systemy partyjne. Zagadnienia teorii i praktyki politycznej. Lublin: Wydawnictwo Uniwersytetu Marii Curie-Skłodowskiej. 